\title{
"WHAT DO I HAVE TO KNOW TO TEACH HISTORY WELL?" \\ KNOWLEDGE AND EXPERTISE IN HISTORY TEACHING - A PROPOSAL ${ }^{1}$
}

DOI: http://dx.doi.org/10.17159/2223-0386/2017/n18a2

Christian Heuer

Mario Resch

University of Education Heidelberg

University of Education Heidelberg

Germany

Germany

heuer@ph-heidelberg.de

resch@ph-heidelberg.de

\author{
Manfred Seidenfuß \\ University of Education Heidelberg, Germany \\ manfred.seidenfuss@ph-heidelberg.de
}

\section{Abstract}

Recent international research has made it clear that empirical educational research and investigations of individual subject didactics are paying increasing attention to the quality of History teachers. History didactics is now attempting to answer one of the key questions about the professionalization of History teachers: How does expertise arise from knowledge and what does it take to teach History well and effectively? This contribution presents the Heidelberg Model for Competence in History Teaching (Heidelberger Geschichtslehrerkompetenzmodell: HeiGeKo) in an attempt to initiate an international discussion about domainspecific profiling of professional conduct in History teaching from theoretical, research methodological, and pragmatic perspectives.

Keywords: History Teachers as Educators; Competencies; Knowledge and Expertise; History Education.

\section{Introduction}

The following suggested discussion is centered on the key question in History didactics about the relationship between knowledge and expertise with respect to the competent conduct of educators who teach history (Husbands, 2011). Or, more simply and more concretely, about one of the current "fundamental questions" (Thünemann, 2016:44) of (not only) History didactics: What does

1 This publication was made possible through funds provided by the State of Baden-Wuerttemberg and the Research Colleges at the Universities of Education in Heidelberg and Ludwigsburg within the framework of the program for research and young researchers entitled "Effective Competence Diagnosis in Teacher Training (EKoL)". 
one, as a teacher, really need to know in order to be able to do something? From the perspective of History didactics, which, as the "science of historical learning" (Rüsen, 2013:254), generates precisely this knowledge that one needs to do something - namely, to teach history - a question also related to teacher education emerges: "To what extent is it possible to synthesize competence through the transfer of knowledge?” (Neuweg, 2015:28; authors' translation).

Thus, the institutionalized professionalization process for History instructors, which is understood as an individual development process of the career biography, is the central point of the following theoretical deliberations about competence. Based on the underlying paradigm of the knowledgebased expert, knowledge and competence, as well as on the convictions and actions of the History instructor, represent the focus of the research interest. This is about professional knowledge as the cognitive portion of competence "that is required for the accomplishment of professional tasks" (Bromme, 2014:49; authors' translation), and about the connection between knowledge and competence that is relevant for practice.

\section{History didactics as a knowledge-generator}

Within research on teacher education and according to the general concept of "Professional Competence", both cognitive and affective aspects of competence are recorded, both of which need to be understood as valuable characteristics of a teacher's professionalism (Baumert \& Kunter, 2006).

From this research, one learns that the quality of an individual teacher in action depends on aspects of her/his competence related to her convictions, her motivational guidance, and her capabilities for professional self-discipline and professional knowledge. The concept of competence underlying this approach defines competence in combination with these newer research approaches within teacher education, namely as something that is domain-specific, multidimensional and that includes an in-built ability to perceive and solve problems, whilst also being flexible and able to be taught (Weinert, 2001).

Based on the premise that the professional competence of History teachers is only domain-specific, a more professional model for judging competence in action in the History classroom has been developed, known as the Heidelberg Model for Competence in History Teaching (HeiGeko) (see Image 1). This model was design within the framework of the Research College at the University of Education in Heidelberg, Germanys' program for "Effective 
Competence diagnosis in Teacher Training"(EKoL). Within the framework of this interdisciplinary research college, the competence development of prospective teachers is empirically examined in the course of their training. In this context, the presented model was theoretically modelled on the basis of the scientific proposals available so far and tries to record the facets of knowledge empirically by so called vignette tests. With its help, we are trying to make a model of domain-specific facets of knowledge, abilities, and skills that a teacher needs in order to teach history as a narrative mode of sensemaking, in a high-quality way that is effective and successful with respect to student performance (Hasberg, 2010; Jung \& Thünemann, 2007; Sauer, 2012).

\section{Image 1: Heidelberg Model for Competence in History Teaching (HeiGeKo)}

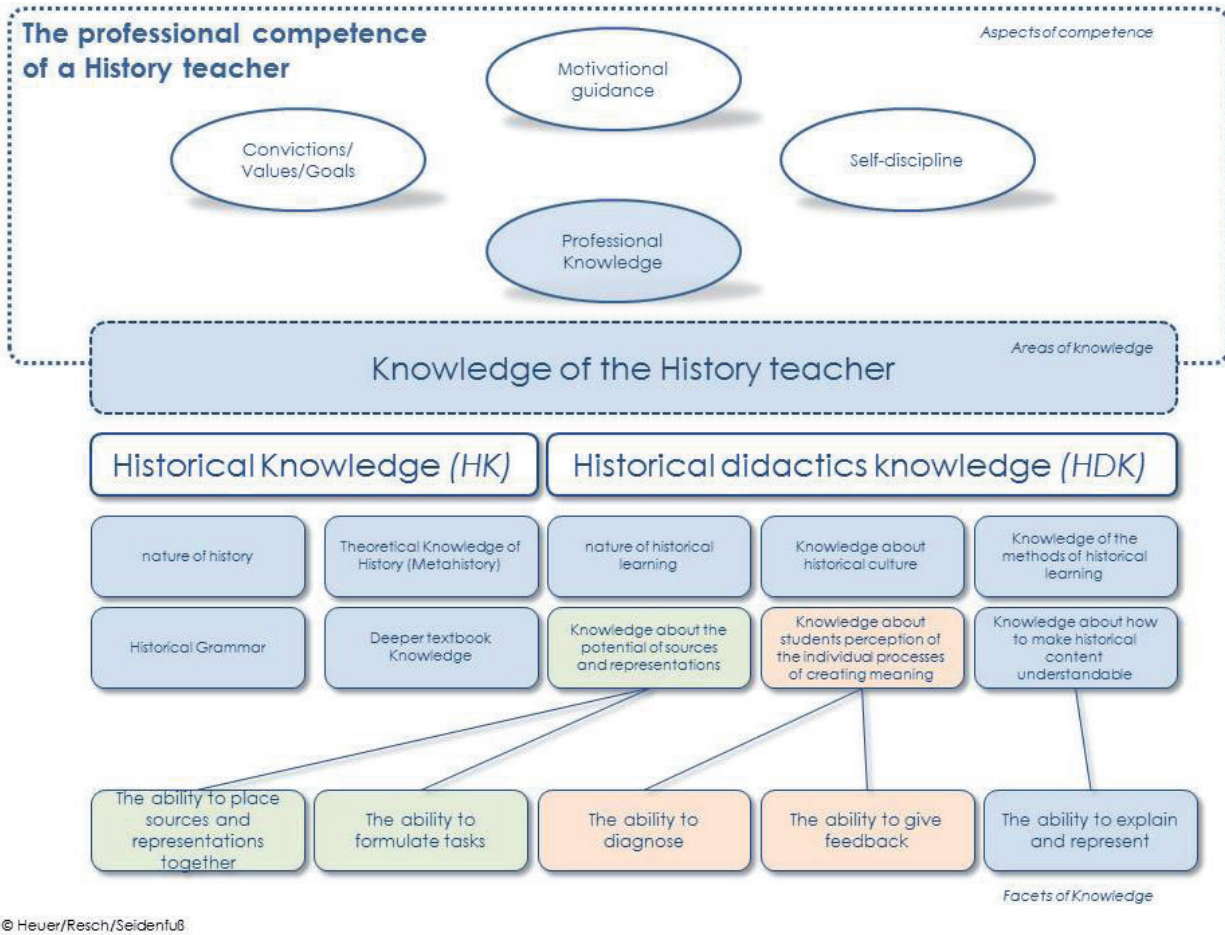

Source: Compiled by authors.

In terms of the professional competence of instructors, there is a broad general consensus within international research that knowledge and competence represent the central components of professional knowledge. The theoretical taxonomy of teacher knowledge, first presented in 1986 by the American psychologist, Lee S. Shulman (Shulman, 1986; 1987), which consists of 
Pedagogical Knowledge (PPK), Content Knowledge (CK), and Pedagogical Content Knowledge (PCK), is now internationally established and has initiated numerous empirical studies (Depaepe, Verschaffel \& Kelchtermans, 2013). Within empirical research on the professionalization of teachers and following Shulman, it is assumed that a broad cross-linking of individual areas of knowledge is an important precondition for high quality instructional conduct and, accordingly, that the action competence of instructors derives from a "multiple knowledge base" (Herzog, 1995:261; authors' translation).

The knowledge areas of historical knowledge $(\mathrm{HK})$ and historical didactics knowledge (HDK), in particular, have a central role in the competent activity of History instructors in their specific domain. In order to operationalize the Heidelberg model for competence in History teaching (HeiGeKo), the knowledge areas HK and HDK were therefore profiled domain specifically by theory-based modeling of individual knowledge facets.

\section{Knowledge of History}

We understand the knowledge area $\mathrm{HK}$ as "the disciplinary knowledge about the subject content" (Bromme, 1995:107; authors' translation) of History, insofar as it has been generated by and legitimized in the discourse of historical science (historical research, History theory, and History didactics). This area of knowledge covers formal, content-based, theoretical, declarative, and procedural aspects of knowledge (see Neuweg, 2011:454; Fenstermacher, 1994) and it can be divided analytically, based on theory, into four interdependent facets of knowledge. Because History, as a subject, does not merely adopt and simplify the results of highly specialized historical research but, rather, transforms them, it can also be said that curricular knowledge represents a special facet of historical knowledge (deeper "textbook knowledge") (Neuweg, 2011:457). This curricular knowledge of the History instructor is extremely culturally specific and contains differing narratives that depend on the country and region (see Gautschi, 2017). The History instructor also requires profound knowledge about the way in which the science of History functions as a science ("conceptualizations of the discipline") (Husbands, 2011:87) about how historical knowledge is generated and legitimized, as well as about how historians work when they occupy themselves academically with History (the nature of history).

This knowledge primarily covers the historical investigative procedures of heuristics, criticism, interpretation, and representation. The nature of history 
facet is closely related to the facet of historical-theoretical knowledge. We thus describe the reflective knowledge of History instructors with which they can understand what they are doing when they occupy themselves with "History". Therefore, this facet of knowledge consists of more than awareness of the procedures of historical science; it is, essentially, the theory of understanding historical science (Rüsen, 2013:24) and it reflects, amongst other things, the difficulty and scope of historical understanding. In the course of time, every science, including historical science, has developed its own language, with which it can record and describe its domain-specific, in this case, historical phenomena. Understanding the grammar of this scientific language and its "procedural concepts" (Husbands, 2011:87), is essential for comprehending and teaching History (the grammar of the historical). In particular, the impossibility of having a comprehensive curricular knowledge of History requires command of the central categories (time, event, progress, development, etc.) and terms (revolution, domination, industrialization, etc.) of historical thinking, in order to understand current and presented narratives as the creation of meaning and to actually narrate historically: "They are not what history is about but they shape the way we go about doing history" (Lee \& Ashby, 2000:199).

Both professional historians and History instructors possess this kind of historical knowledge. But History instructors also know how to transform this knowledge so that it is effective for individual students in terms of the learning and educational situation. History didactics, as a science, provides a system of categories and principles that gives students access to History as a narrative for creating meaning or to empower them to create their own historical meaning through experiencing time. We call this knowledge, which consists of propositional aspects of knowledge, case studies, and knowledge about strategic action, knowledge of History didactics (Dick, 1994:134).

\section{Knowledge of History didactics}

By now, the fact that the actual object of the subject of History is not the past is really trivial. The past is not available to us; it no longer exists. Thus, when teaching history, one occupies oneself with something that is no longer there by trying to find answers to current historical questions. In order to profile this field of knowledge as domain-specific knowledge of History didactics, we differentiate between six aspects of knowledge within the field. Knowledge about the didactics of History (KHD) connects the domain-specific historical 
knowledge of a History instructor to the area of interdisciplinary pedagogicalpsychological knowledge (PPK), which, according to Shulman, is the "amalgam" between the two (Shulman, 1986:23). Knowledge about History didactics is needed to make the contents of History understandable and at the same time accessible to learners through a narrative creation of meaning (creating and understanding meaning; see Shulman, 1986:9; Neuweg, 2011:457).

Since its establishment as an independent scientific discipline, the didactics of History has addressed the task of "investigating the constitution and establishment of historical awareness as a significant factor of human selfidentity and as an essential prerequisite for sound social practice descriptively/ empirically and, simultaneously, regulating it didactically and normatively" (Bergmann \& Rüsen, 1978:9; authors' translation). In terms of teaching history, one of its tasks, regarding "the theoretical and methodological tools of historical science, expressed conceptually by historical theory, is didactically based reflection on how to distinguish what is worth learning from what is possible to learn" (Bergmann \& Rüsen, 1978:13; authors' translation). The didactics of History, as an independent discipline, is thus "an institutional form of reflection about historical thinking" (Pandel, 2013:21; authors' translation), with its own categories, terminology, and fundamental principles. As the didactics of a science and as a didactics of "thinking about everyday life" (Pandel, 2013:21; authors' translation), it is committed to life in the contemporary world: "to be able to teach history competently naturally requires familiarity with the subject-specific forms and contents of historical thinking. But the scientific treatment of historical learning is not limited by these prerequisites" (Rüsen, 2013:253; authors' translation). KHD is thus not solely practice-oriented knowledge about actions as competence; instead, it extends beyond a pure transfer function in schools. This facet of knowledge therefore deals with having command of historical-didactic principles such as perspectivity, contemporary relevance, source orientation, or procedures (e.g., subject analysis, merit judgment, value judgment) as the fundamental "grammar of the subject" (Mayer, 2009:115.).

Hence, in the model presented here, KHD, as an independent facet of the knowledge area of subject didactics, is modeled without reference to the action situation in teaching and to the concrete application situation (nature of historical learning). Teaching history at school, however, represents just one institutionalized sphere of encountering history. The past, whose absence is present is present esthetically, politically, and scientifically, in the real-life 
world in a wide variety of forms staged by the media, as published research results and instruction, but also as historical movies, reenactments, or graphic novels. Since the 1980s, this ensemble of representations of the past has been described by the term historical culture (Rüsen, 1994) and it has become one subject of research. However, this collection of "cultural realities" (Konersmann, 2006:58; authors' translation), which is both formative and characterized cannot be adequately explained and understood with the logic and rationality of scientific History and deeper textbook knowledge alone. Hans-Jürgen Pandel, an expert in History didactics, has described this very accurately with the phrase "knowing a lot is not enough" (Pandel, 2009; authors' translation). History instructors thus need knowledge about historical culture (Pandel, 2007:40); in other words, knowledge about the various logics and grammars of historical culture stagings and about their staging in the media (knowledge about historical culture), in order to find and produce reallife points of reference for historical learning. Ultimately, designing conditions for learning and communication in History classes is the basic daily task of a History instructor. We describe the knowledge about rules of History didactics as the facet of knowledge that deals with the methods of historical learning. This methodological knowledge, understood as the knowledge required for the domain-specific design of learning situations within the framework of History classes, comprises knowledge about subject-specific lesson planning, about the various subject-specific teaching methods (e.g., historical project work), and about the corresponding basic methodological principles (e.g., enquiry-based learning). However, it does not include the practice of historical learning, i.e., applying rules in concrete History teaching (Pandel, 2013:249).

The knowledge facet "knowledge about the historical-didactic potential of sources and representations" covers the selection and processing of sources connected to the planning and execution of history teaching. In order to be able to provide answers to historical questions, one looks for, within the framework of the historical method, "the presence of the materials" (Droysen, 1977:9; authors' translation), so that they can be collected and ordered: "And history is just this - an undertaking in which materials are collected" (Danto, 1980:17). These materials consist of sources and representations from which possible answers can be generated, in order to "be able to tell stories that one needs to orient oneself in the temporal dimension of one's own life practice" (Rüsen, 2013:258; authors' translation). Thus, History instructors must be in a position to examine sources and representations in terms of their historicaldidactic potential, in order to employ them for the staging of historical 
learning processes, so that learners can gain historical competencies.

Knowledge about "students' perception of the historical and individual processes of creating meaning" is described in a further facet of knowledge. This facet refers to knowledge about "conceptions and preconceptions that students of different ages and backgrounds bring with them to the learning of those most frequently taught topics and lessons" (Shulman, 1986:9). Taking students' perceptions into account is essential for staging learning opportunities that take the development of competence and the interests of students seriously. History instructors must be able to recognize the patterns of historical creation of meaning in students' remarks and accept them as such, in order to diagnose students' knowledge and processes of understanding, so that they can react appropriately in the teacher-student interaction. This will allow them to employ target-oriented interventions for the creation of reflected historical awareness and to ensure increased competence of students (Pandel, 2007:46). Giving explanations is the key activity of teaching when dealing with the representation of the historical as "history" (Leinhardt, 1997:231), because History connects historical events meaningfully by locating them in a temporal relationship between cause and effect (Pandel, 2017:121). History as an explanation is the answer to historical questions about why. Following the studies on analytical historical philosophy, the realization that History, as a meaningful, i.e., explanatory relationship of historical events always has a narrative character, has gained broad general acceptance. History is thus, simultaneously, always both narrative and explanation (Danto, 1980:231). Teaching History thus always takes the ability to tell stories about History for granted, because the past, which no longer exists, has to be represented and collectively negotiated as "History" in classroom activities. In terms of controlling cognitive processes in History classes, instructors should therefore be in a position to make historical connections, concepts, and interpretations understandable for learners in an appropriate way, using suitable forms of conversational communication. What is important here, above all, is the structuring of the learning target, explaining, and making concepts, developmental lines, or traditions understandable, maybe with reduced complexity, where appropriate. Therefore, the knowledge facet "knowledge about how to make historical content understandable", describes access to subject-specific options for representation and explanation that determine the choice of appropriate teaching methods (teaching-learning concepts, forms of work) and social forms for History classes. On this basis, it is possible to give individual students goal-oriented feedback. 
The historical knowledge and knowledge about History didactics that History instructors have gathered during their training and that is available to them can, however, only affect students via instructional activities (see Shulman, 1986; Neuweg, 2011:457). Consequently, it first becomes practical and a "competence" when it is applied to concrete teaching situations.

\section{Knowledge in teachers' actions}

We assume that, for the transfer of the Heidelberg Model for Competence in History Teaching (HeiGeKo) to concrete teaching practice, History instructors can act competently in a historical-didactically relevant situation (for example, formulating suitable learning tasks) if they possess a repertoire of relevant domain-specific knowledge (historical and historical-didactic knowledge), relevant domain-unspecific facets of knowledge (PPK), as well as knowledge, skills, and abilities that allow them to master emerging problems and difficulties during the formulation of learning tasks. However, this by no means says that, even when instructors possess this knowledge, they can also act in a knowledge-driven way in this specific situation. Practice, with all of its complexity, too often resists the application of various knowledge areas: "In real-world practice, problems do not present themselves to the practitioner as given. They must be constructed from the materials of problematic situations which are puzzling, troubling, and uncertain" (Schön, 1983:4). Finding problems always precedes solving problems. In order to solve a problem, instructors must want to notice it, as such, then interpret this awareness on the basis of their professional knowledge (knowledge-based reasoning), in order to, finally, act competently. Nevertheless, whether professional competence is converted into performance, understood as observable professional activity of an instructor, depends on other conditions and requirements, including, amongst others, motivation (Voss et al., 2015:189). The relationship between knowledge and action thus acquires a further dimension that has proved to be crucial for the basic concept of competence: "The relationship between knowledge and action is motivational, not logical” (Herzog, 1995:263). Accordingly, the application of knowledge is not controlled by knowledge. Activity routines do not become part of such situations; instead, new situations constantly occur that can only be resolved competently. This "user intelligence" (Neuweg, 2011:464; authors' translation) cannot, in turn, be knowledge-shaped. Thus, the two areas - professional knowledge and professional teaching awareness - constitute competence, i.e., competent teacher activity. 
In addition to individual motivation ("teacher enthusiasm"), convictions and subjective theories ("teacher beliefs") exert a strong influence on the competent activity of History instructors in terms of "competence" related to the choreography of teaching (Voss, 2011). In particular, a constructivist conviction, whereby learners are regarded more as actors in their own learning processes and less as recipients, together with a strong motivation and fascination for the subject being taught, ultimately lead to better student achievements (Staub \& Stern, 2002). The individual convictions, subjective theories, motivational situation, and value concepts represent the background against which instructors recognize problems in the relevant situations as such and combine these with their professional knowledge, so that they can act adequately, according to the situation. The transitions between the individual facets of knowledge from the various areas, the convictions and subjective theories of the instructors, as mental representations, are thereby fluid. Knowledge can only be separated with great difficulty from attitudes and subjective theories (Fenstermacher, 1994:29): "This is related to the fact that, in the mind of the teacher, components of knowledge, beliefs, conceptions and intuitions are inextricably intertwined" (Verloop, Van Driel \& Meijer, 2001:446). Therefore, in the model presented here, the convictions and subjective theories of History instructors are differentiated heuristically, based on their "epstemic status" (Fenstermacher, 1994:29), from areas of knowledge and their facets, according to whether they are generated by science or legitimized by beliefs (see Baumert \& Kunter, 2011:41).

\section{Perspectives for the practical training of History teachers}

Within the field of History didactics, we know only little about how teachers orient themselves in their everyday teaching, what they refer to and from where they derive these points of reference - summarized as "knowledge in action" (Schön, 1983). The relationship between "formal" and "practical" knowledge (see Fenstermacher, 1994) in terms of the development of competence in professional actions and, in particular, in terms of individual facets of competence such as, for example, the diagnosis of historical thinking remains unknown to us: how does the explicit "academic knowledge" of the novice become implicit "practical knowledge" and competence of the expert? The available empirical results demonstrate that novices are not able to 
competently apply their doubtlessly available knowledge in relevant, complex, and domain-specific teaching situations. ${ }^{2}$

The didactics of History, as an independent science, makes space for possibilities available-Jeismann once termed this, very appropriately, a "system of coordinates" (Jeismann, 1988:6; authors' translation) - in which History instructors can feel safe, if they know it. Academically transferred knowledge of History didactics (the nature of historical learning) is thus the necessary precondition for professional action competence, but it does not generate "rules for practice" (Jeismann, 1988:6; authors' translation). The didactics of History is necessary but not sufficient for competent action in History classes (Heuer, 2017). The question about how knowledge transmitted at the tertiary level becomes competent instructor action during teaching represents, not least, an investigative-methodological challenge for empirical research (Resch, Seidenfuß \& Vollmer, 2017).

\section{Conclusion}

With the Heidelberg Model for Competence in History Teaching (HeiGeKo), presented here, we have attempted to develop a model that profiles the didactics of History and whose concreteness could make its mark on the international discussion about the professional competence of History teachers. We have tried to describe the professional competence of the History teacher, the competent teaching of History, as a process in which the knowledge areas of knowledge of History, knowledge of History didactics, motivation and teaching perception are the central variables guiding action in History classrooms. From a professional theoretical and domain-specific point of view, knowledge of History didactics in particular plays a central role in order to be able to perceive, classify and assess problems that occur as such. Our theory-based model can thus be understood as an attempt to clarify relevant elements of History teaching, but does not claim to represent the practice of History teaching. When applied to the relationship between theory and practice in History teacher training, this means that the academic knowledge of History didactics imparted in academia cannot lead to the knowledge of the concrete teaching situation, but the independent way of thinking about History is in this sense the basis for reflection on which

2 Compare results presented at the Conference of the South African Society for History Teaching and the International Society of History Didactics on 13 September 2017 in Vanderbijlpark (South Africa) entitled "Diagnosing" and "being able to formulate tasks" - (Belonging) to the vignette-based gathering of didactical competences of History teachers at the beginning of the practical apprenticeship. 
didactic decisions are made. In this respect, we are therefore talking about the History teacher's didactic professionalism, which we believe is the central professional skill of the History teacher. Thus, History didactics as the central vocational science of the History teacher becomes the focus of the discussion about what a History teacher needs to know in order to teach History in a high quality way.

\section{References}

Baumert, J \& Kunter, M 2011. Das mathematikspezifische Wissen von Lehrkräften, kognitive Aktivierung im Unterricht und Lernfortschritte von Schülerinnen und Schülern. In: M Kunter, J Baumert, W Blum, U Klusmann, S Krauss \& M Neubrand (eds.). Professionelle Kompetenz von Lehrkräften. Ergebnisse des Forschungsprogramms COACTIV. Münster: Waxmann.

Baumert, J \& Kunter, M 2006. Stichwort: Professionelle Kompetenz von Lehrkräften. Zeitschrift für Erziehungswissenschaft, 4:469-520.

Bergmann, K \& Rüsen, J 1978. Zum Verhältnis von Geschichtswissenschaft und Geschichtsdidaktik. In: K Bergmann \& J Rüsen (eds.). Geschichtsdidaktik. Theorie für die Praxis. Düsseldorf: Schwann.

Bromme, R 2014. Der Lehrer als Experte. Zur Psychologie des professionellen Wissens. Münster: Waxmann.

Bromme, R 1995. Was ist "pedagogical content knowledge"? Kritische Anmerkungen zu einem fruchtbaren Forschungsprogramm. Zeitschrift für Pädagogik, Beiheft 33:105-115.

Danto, A C 1980. Analytische Philosophie der Geschichte. Frankfurt a. M.: Suhrkamp.

Depaepe, F, Verschaffel L \& Kelchtermans, G 2013. Pedagogical content knowledge: A systematic review of the way in which the concept has pervaded mathematics educational research. Teaching and Teacher Education, 34:12-25.

Dick, A 1994. Vom unterrichtlichen Wissen zur Praxisreflexion. Das praktische Wissen von Expertenlehrern im Dienste zukünftiger Junglehrer. Bad Heilbrunn: Klinkhardt.

Droysen, JG 1977 [1857]. Historik. Rekonstruktion der ersten vollständigen Fassung der Vorlesungen (1857). Grundriß der Historik in der ersten handschriftlichen (1857/58) und in der letzten gedruckten Fassung (1882). Edited by Peter Leyh. Stuttgart. 
Fenstermacher, GD 1994. The knower and the known. The nature of knowledge in research on teaching. Review of Research on Teaching, 20:3-56.

Hasberg, W 2010. Historiker oder Pädagoge. Geschichtslehrer im Kreuzfeuer der Kompetenzdebatte. Zeitschrift für Geschichtsdidaktik, 9:159-179.

Herzog, W 1995. Reflexive Praktika in der Lehrerinnen- und Lehrerbildung. Beiträge zur Lehrerbildung, 13, 3:253-273.

Heuer, C 2017. "Whitewater Canoeists" or "Rule Applying Automats"? Public History Weekly, 5, 18. Available at https://dx.doi.org/10.1515/phw-2017-9232. Accessed on 1 November 2017.

Husbands, C 2011. What do history teachers (need to) know? A framework for understanding and developing practice. In: I Davies (ed.). Debates in history teaching. London; New York: Routledge.

Jeismann, K-E 1988. Geschichtsbewußtsein als zentrale Kategorie der Geschichtsdidaktik. In: G Schneider (ed.). Geschichtsbewußtsein und historisch-politisches Lernen. Pfaffenweiler: Centaurus.

Jung, M \& Thünemann, H 2007. Welche Kompetenzen brauchen Geschichtslehrer? Für eine Debatte über fachspezifische Standards in der Geschichtslehrerausbildung. Zeitschrift für Geschichtsdidaktik, 6:243-252.

Konersmann, R 2006. Kulturelle Tatsachen. Frankfurt a. M.: Suhrkamp.

Lee, P \& Ashby, R 2000. Progression in historical understanding among students ages 7-14. In: P N Stearns, P Seixas \& S Wineburg (eds.). Knowing teaching \& learning history. National and international perspectives. New York; London: NYU Press.

Leinhardt, G 1997. Instructional explanations in history. International Journal of Educational Research, 27, 3:221-232.

Mayer, U 2009. Kategorien. In: U Mayer, HJ Pandel, G Schneider \& B Schönemann (eds.). Wörterbuch Geschichtsdidaktik. Schwalbach/Ts.: Wochenschau.

Neuweg, GH 2015. Das Schweigen der Könner. Gesammelte Schriften zum impliziten Wissen. Münster: Waxmann.

Neuweg, GH 2011. Das Wissen der Wissensvermittler. In: E Terhart, H Bennewitz \& M Rothland (eds.). Handbuch der Forschung zum Lehrerberuf. Münster: Waxmann.

Pandel, HJ 2017. Geschichtstheorie. Eine Historik für Schülerinnen und Schüler-aber auch für ihre Lehrer. Schwalbach/Ts.: Wochenschau.

Pandel, HJ 2013. Geschichtsdidaktik. Eine Theorie für die Praxis. Schwalbach/Ts.: Wochenschau. 
Pandel, HJ 2009. Geschichtskultur als Aufgabe der Geschichtsdidaktik: Viel zu wissen, ist zu wenig. In: V Oswalt \& H-J Pandel (eds.). Geschichtskultur. Die Anwesenheit der Vergangenheit in der Gegenwart. Schwalbach/Ts.: Wochenschau.

Pandel, HJ 2007. Geschichtsunterricht nach PISA. Kompetenzen, Bildungsstandards und Kerncurricula. Schwalbach/Ts.: Wochenschau.

Resch, M, Seidenfuß, M \& Vollmer, C 2017. Ein Vignettentest zur Erfassung fachdidaktischer Kompetenzen bei angehenden Geschichtslehrkräften. In: M Waldis \& B Ziegler (eds.). Forschungswerkstatt Geschichtsdidaktik 15. Beiträge zur Tagung "geschichtsdidaktik empirisch15". Bern: Hep.

Rüsen, J 2013. Historik. Theorie der Geschichtswissenschaft. Köln; Weimar \& Wien: Böhlau.

Rüsen, J 1994. Was ist Geschichtskultur? Überlegungen zu einer neuen Art, über Geschichte nachzudenken. In: K Füßmann, HT Grütter \& J Rüsen (eds.). Historische Faszination. Geschichtskultur heute. Köln; Weimar; Wien: Böhlau.

Sauer, M 2011. Kompetenzen für Geschichtslehrer - was ist wichtig und wo sollte es gelernt werden? Ergebnisse einer empirischen Studie. Geschichte in Wissenschaft und Unterricht, 63, 5/6:324-348.

Schön, DA 1983. The reflective Practitioner. How Professionals think in action. New York.

Shulman, LS 1986. Those who understand: Knowledge growth in teaching. Educational Researcher, 15:4-14.

Shulman, LS 1987. Knowledge and teaching: Foundations of the new reform. Harvard Educational Review, 57:1-21.

Staub, FC \& Stern, E 2002. The nature of teachers' pedagogical content beliefs matters for students' achievement gains: quasi-experimental evidence from elementary mathematics. Journal of Educational Psychology, 94:344-355.

Thünemann, H 2016. Probleme und Perspektiven der geschichtsdidaktischen Kompetenzdebatte. In: S Handro \& B Schönemann (eds.). Aus der Geschichte lernen? Weiße Flecken der Kompetenzdebatte. Berlin: Lit.

Voss, T, Kunina-Habenicht, O, Hoehne, V \& Kunter, M 2015. Stichwort Pädagogisches Wissen von Lehrkräften: Empirische Zugänge und Befunde. Zeitschrift für Erziehungswissenschaft, 18:187-223.

Voss, T, Kleickmann, T, Kunter, M \& Hachfeld, A2011. Überzeugungen von Mathematiklehrkräften. In: M Kunter, J Baumert, W Blum, U Klusmann, S Krauss \& M Neubrand (eds.). Professionelle Kompetenz von Lehrkräften. Ergebnisse des Forschungsprogramms COACTIV. Münster: Waxmann. 
Weinert, FE 2001. Concept of competence. A conceptual clarification. In: DS Rychen \& LH Salganik (eds.). Defining and selecting key competencies. Ashland, OH: Hogrefe \& Huber. 